\title{
KEPEMIMPINAN PEREMPUAN MENURUT MASDAR FARID MAS'UDI DAN KIAI HUSEN MUHAMMAD
}

\author{
Ach. Tirmidzi \\ Desa Banuaju Timur Batang-Batang Sumenep Madura | ikon@yahoo.com
}

\begin{abstract}
This research examines Masdar Farid Mas'udi's and Kiai Husein Muhammad's thought on the woman's leadership. According to both, the woman's leadership does not contradict to Islam, because not only man who is entitled to become a leader, but woman also has right as that of man. Masdar Farid Mas'udi and Kiai Husein Muhammad are consistent Muslim thinkers who advocate and defend the woman's rights. They both permit woman to be a leader among the men. It is because, according to them, such permissibility is not by the reason of sex, but rather bythe potential ability the woman has. So that, they add, there are no restrictions and limitations for woman to be a leader. Masdar Farid Mas'udi's and Kiai Husein Muhammad's thought lie on the contextualization of the Islamic text and, at the same time, as a respond against the literal or textual interpretation of the main texts of Islam. The only difference is that Masdar interprets the text as embodied in jurisprudential aspect, while Kiai Husen Muhammad combines historical and jurisprudential approach.
\end{abstract}

Keywords: Women's leadership, Masdar Farid Mas'udi, Kiai Muhammad Husen

Abstrak: Penelitian ini mengkaji pemikiran Masdar Farid Mas'udi dan Kiai Husen Muhammad tentang kepemimpinan perempuan. Kepemimpinan perempuan menurut Masdar Farid Mas'udi dan Kiai Husen Muhammad, tidak bertentangan dalam Islam. Karena menurut Masdar dan Kiai Husen Muhammad, tidak hanya kaum laki-laki yang berhak menjadi pemimpin, perempuanpun juga berhak sebagaimana peran laki-laki. Masdar Farid Mas'udi dan Kiai Husen Muhammad adalah tokoh pembela perempuan yang konsisten dalam memperjuangkan dan membela hak-hak perempuan. Sehingga ia termasuk salah-satu kiai yang membolehkan perempuan jadi pemimpin sebagaimana yang dilakukan oleh kaum laki-laki. Karena menurut 
Masdar dan Kiai Husen Muhammad dibolehkannya bukan terletak pada jenis kelamin, melainkan karena potensi kemampuannya. Jadi menurut keduanya tidak ada larangan dan batasan bagi perempuan menjadi pemimpin. Pandangan dan gagasan Masdar dan Kiai Husen tentang kepemimimpinan perempuan terletak pada kontekstualisasi teks (kritik teks). Bedanya kalau Masdar menafsirkan teks tidak terlepas dengan konsep fikihnya, sedangkan Kiai Husen menafsirkan teks tidak terlepas dari sejarah dan fiqihnya.

Kata Kunci: Kepemimpinan perempuan, Masdar Farid Mas'udi, Kiai Husen Muhammad

\section{Pendahuluan}

Setelah berakhirnya reformasi, perbincangan wacana kepemimpinan perempuan selalu memperoleh perhatian yang sangat besar oleh banyak kalangan. Kesetaraan gender antara lakilaki dan perempuan, merupakan salah satu isu besar dalam pemikiran Islam kontemporer di samping isu demokrasi, relasi agama dan negara. Isu ini muncul dari keperihatinan yang sangat mendalam atas ketertindasan kaum perempuan dan perlakuan tidak adil terhadap mereka hampir dalam seluruh ruang. ${ }^{1}$ Sehingga kesempatan seorang perempuan untuk menempatkan posisi di kursi parlemen, baik di legislatif maupun eksekutif sangatlah terbatas.

Keterwakilan perempuan dalam pemerintahan baik di lembaga eksekutif ataupun legislatif sangatlah penting. Karena perempuan, yang mampu dan memudahkan akses bagi persoalan perempuan untuk mengawasi dan menyuarakan kebijakankebijakan yang masih tidak adil bagi hak-hak perempuan. ${ }^{2}$

Keterlibatan perempuan dalam dunia politik juga menjadi catatan sejarah Nabi Muhammad. Beberapa perempuan pada masa itu turun ke medan perang, berdiskusi di majlis-majlis, menjadi imam shalat, (seperti Ummu Waraqoh ra.), menjadi guru bagi

Adnan Mahmud, Pemikiran Islam Kontemporer di Indonesia, (Yogyakarta: Pustaka Pelajar, 2005), 102.

${ }^{2}$ Ufi Ulfiah, Perempuan di Panggung Politik, (Jakarta: Rahimah, 2007), 19. 
kaum laki-laki, menjadi sumber pendapatan bagi keluarga dan masyarakat dan lain-lain. ${ }^{3}$

Namun banyak kalangan yang berbeda pandangan, termasuk umat Islam sendiri tidak setuju terhadap masuknya perempuan di wilayah publik. Aktivitas publik merupakan hak asasi setiap manusia, termasuk perempuan. Perempuan mempunyai hak yang sama, sebagaimana apa yang selama ini dilakukan oleh seorang laki-laki termasuk memimpin dalam wilayah publik.

Sejarah kepemimpinan perempuan dalam Islam memang tidak begitu mendapat porsi pembahasan yang cukup proporsional. Dalam wacana Islam di Indonesia, persoalan ini juga masih jarang dibicarakan. Intelektual seperti Nur Cholis Masjid yang panggilan akrabnya Cak Nur, tokoh pembaharu Islam di Indonesia misalnya, pernah dikritik oleh kalangan feminis karena secara spesifik ia tidak pernah menyentuh tema-tema perempuan dalam Islam. ${ }^{4} \mathrm{Hal}$ ini sangat berbeda dengan fenomena Islam di Timur Tengah seperti Hasan Hanafi, Muhammad Imarah, Muhammad Arkoun, Abdullah An-Naim, Nasr Hamid Abu Zaid, dan Muhammad Sahrur. Meskipun secara biologis mereka lakilaki, namun mereka menaruh perhatian pada isu kepemimpinan perempuan. Bagi mereka persoalan perempuan dalam Islam sama pentingnya dengan persoalan peradaban Islam secara umum. ${ }^{5}$

Selain tidak mendapat porsi atau kesempatan yang signifikan, perempuan di wilayah publik juga dikarenakan adanya sejumlah rambu-rambu yang didesain untuk menjegal atau menghalangi perempuan tampil sebagai pemimpin publik. Ironisnya, sebagian masyarakat menganggap hal ini sebagai bukti ketidakmampuan perempuan di ranah publik. Banyak kalangan menganggap bahwa rendahnya partisipasi perempuan di dunia publik merupakan hal yang natural (takdir ketidakmampuan) saja. Tidak ada kesadaran bahwa rendahnya partisipasi itu karena sejarah keberadaan

\footnotetext{
${ }^{3}$ Ibid., 43.

${ }^{4}$ Syafiq Hasyim, Sejarah Kepemimpinan Perempuan, (Jakarta: P3M, tt.), 4.

${ }^{5}$ lbid., 4.
}

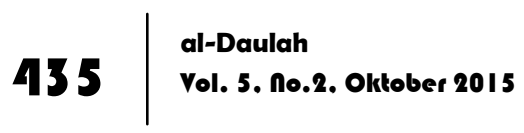


perempuan sebagai makhluk yang memiliki hak selalu dinafikan (tidak dihitung) oleh kultur atau tradisi maupun oleh struktur sosial-politik yang ada. ${ }^{6}$

Jika pandangan ini masih betah menetap dalam mindset (pola pikir) bangsa Indonesia, maka hak perempuan yang bebas berpartisipasi akan sangat sulit diwujudkan. Dirampasnya hakhak perempuan bukan karena tidak adanya deretan undangundang yang memayunginya. Problem terbesar bukan pada undang-undang tetapi karena memang hak itu tidak diberikan atau bahkan dirampasnya.

Peranan perempuan di pelbagai bidang kehidupan, kiranya tidak perlu diragukan lagi. Bukan saja di dalam bidang biologis dan alamiah saja, tetapi di bidang-bidang yang lain juga mempunyai hak dan peran yang sama. Tentu saja ada perbedaan besar kecilnya peranan di suatu bidang tertentu, sesuai dengan sifat-sifat yang berbeda antara perempuan dan laki-laki. Adakalanya di suatu bidang, perempuan punya peranan lebih besar dan adakalanya di bidang yang lain, laki-laki punya peranan lebih besar. ${ }^{7}$

Kepemimpinan laki-laki atas perempuan dalam pandangan beberapa ulama tidak hanya sebatas dalam lingkup keluarga, tetapi meliputi pula kepemimpinan dalam masyarakat (kepemimpinan publik) dan politik. Sehingga perempuan mendapatkan kesempatan yang sama dengan laki-laki dalam mengaktualisasikan potensinya sebagai pemimpin.

Selain realitas di atas, yang menjadi penghalang terhadap peran perempuan dalam wilayah publik, yaitu tidak terlepas dari dua alasan dan larangan keterlibatan perempuan dalam bidang kepemimpinan. Pertama, adanya ayat al-Qur'an yang populer dijadikan rujukan yaitu surat an-Nisa' ayat 34 yang berbunyi:

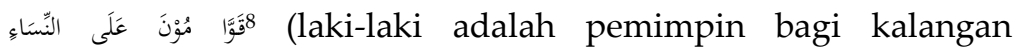

${ }^{6}$ Ulfah, Partisipasi Perempuan dalam Politik, 83.

${ }^{7}$ Abdul Muchit Muzadi, Fiqih Perempuan Praktis, (Surabaya: Khalista, 2005), 4.

${ }^{8}$ Surat An-Nisa', Jus 4, Ayat 34. 
perempuan). Kedua, juga hadis yang menyatakan ${ }^{9}$ (tidak akan beruntung suatu kaum yang menyerahkan suatu urusannya kepada perempuan).

Kedua dalil ini mempunyai keterkaitan dalam memperkuat argumentasi ketidakbolehan perempuan dalam memegang kepemimpinan. Adapun alasan lain, baik ayat maupun hadis tersebut, mengisyaratkan bahwa kepemimpinan hanya untuk kaum laki-laki, dan menegaskan keharusan perempuan mengakui kepemimpinan ini. Namun dalam kalangan mufassir kontemporer melihat ayat dan hadis tersebut tidak harus dipahami seperti itu, apalagi ayat dan hadis tersebut berkaitan dengan persoalan rumah tangga.

Surat an-Nisa' ayat 34 secara jelas menyajikan tentang pembagian kerja antara suami dan istri. Sementara hadis yang mengatakan, "Tidak beruntung suatu kaum yang menyerahkan urusannya kepada perempuan", tidak digariskan secara umum. Hadis ini berkaitan dengan suatu peristiwa, seperti yang telah diriwayatkan Bukhori, Ahmad, an-Nasa'i, dan Tirmidzi melalui Abu Bakrah. "Ketika Rasulullah SAW mengetahui bahwa masyarakat Persia mengangkat putri Kisrah sebagai penguasa

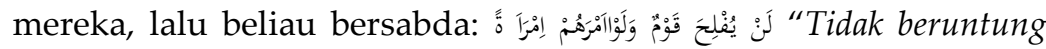
suatu kaum yang menyerahkan urusan mereka kepada perempuan". ${ }^{10}$

Inilah hadis yang selama ini dijadikan pegangan untuk melarang perempuan tampil sebagai pemimpin masyarakat, mulai dari lembaga kemasyarakatan sejenis yayasan, ormas, (kecuali hanya berstatus underbouu), sampai dengan kepemimpinan politik, khususnya kepemimpinan negara (alImamah al-'uzmah). ${ }^{11}$

Hadis di atas dari sudut sanad memang dinilai sahih. Akan tetapi ada beberapa hal yang perlu dicatat. Pertama, karena

\footnotetext{
9 Shohih Bukhori, Jus 2, 82. dan Sunan Tirmidzi, Bab al-Fitan, 75.

${ }^{10}$ Ibid., 82

"Masdar Farid Mas'udi, Islam dan Hak-Hak Reproduksi Perempuan, Dialog Fiqih Perempuan, (Bandung: Mizan, 1997), 69.
} 
statusnya sebagai hadis ahad (yang diriwayatkan oleh satu mata rantai), maka bagaimanapun menurut para ahli hadis sendiri tidak bisa memberikan keyakinan yang penuh atas keotentikannya. Artinya kita tidak bisa mengatakan bahwa demi Allah (wallahi) Rasulullah telah bersabda begitu. Kedua, hadis itu baru dikemukakan oleh perawinya, Abu Bakrah, seorang diri, kira-kira 23 tahun sesudah Rasulullah SAW wafat. Selama itu, tidak ada seorang sahabat yang diketahui ikut mewartakannya, mekipun kita bisa merasakan betapa seriusnya isi hadis tersebut. Ketiga, hadis itu dikemukakan oleh perawi pada saat-saat konflik antara 'A'isyah dengan Sayyidina Ali ra. Keempat, hadis itu dinyatakan oleh Rasulullah demikian menurut perawi, dalam konteks kekaisaran Parsi yang notabene memang menyimpan kebencian terhadap Islam.

Hadis di atas juga dikaitkan, dengan masyarakat Persia ketika itu dan bukan berlaku umum dalam segala urusan. Dalam konteks melihat hadis dan menafsirkan surat an-Nisa' ayat 34 dapat dilihat mengenai adanya hak-hak politik kepemimpinan kaum perempuan seperti yang diungkapkan dalam surat at-Taubah ayat 71 yang artinya "Dan orang-orang yang beriman, laki-laki dan perempuan, sebagian mereka adalah kekasih bagi sebagian yang lain. Mereka menyuruh untuk mengerjakan yang makruf, mencegah yang mungkar, mendirikan salat, menunaikan zakat, dan mereka taat kepada Allah dan Rasul-Nya. Mereka itu akan diberi rahmat oleh Allah. Sesungguhnya Allah Maha Perkasa lagi Maha Bijaksana". (Qs. AtTaubah: 71) $)^{12}$

Secara umum kaum laki-laki dan perempuan mempunyai hak yang sama dalam setiap aspek kehidupan seperti seruhan untuk berbuat yang makruf dan menjauhkan yang munkar. Termasuk juga di dalam masalah politik, perempuan mempunyai hak yang sama sebagaimana seorang laki-laki.

12 Yayasan Penterjemah Al-Qur'an, Surat At-Taubah, Jus 10, Ayat 7, 291. 
Suatu fakta sejarah bahwa 'A'isyah, istri Rasulullah, pernah memimpin pasukan dalam perang melawan khalifah Ali bin Abi Thalib. Keterlibatan 'A'isyah dalam peperangan itu menunjukkan partisipasi kaum muslimin dalam bidang politik praktis sekalipun. ${ }^{13}$

Penelitian ini akan mengangkat bacaan dan wacana baru tentang partisipasi perempuan, menurut pandangan Masdar Farid Mas'udi dan Kiai Husen Muhammad. Karena selama ini, wacana yang berkembang khususnya di Indonesia perempuan selalu dinafikan di bawah kaum laki-laki. Isu dan tindakan yang seperti inilah, yang seharusnya dilakukan oleh kaum perempuan sendiri demi mengubah realitas politik yang mendiskriditkan terhadap peran politik perempuan saat sekarang ini. Karena tidak menutup kemungkinan, banyak kaum perempuan yang lebih mampu di atas kaum laki-laki. Persoalan ini juga harus menjadi pelajaran bagi seluruh warga negara, tanpa membedakan ia laki-laki atau perempuan. Demi terciptanya realitas politik yang ramah dan mencerminkan rasa keadilan dan persamaan kedudukan atas sesama manusia, laki-laki ataupun perempuan.

\section{Konsep Kepemimpinan Perempuan Menurut Masdar Farid Mas'udi}

\section{Riwayat Hidup dan Pendidikan}

Masdar Farid Mas'udi lahir dari ibunda Hj. Hasanah, di Dusun Jombor, Cipete, Cilongok, Purwokerto, tahun 1954. Masdar Farid Mas'udi merupakan putra dari Kiai Mas'udi bin Abdurrahman, seorang Kiai yang kesehariannya mengisi pengajian majlis ta'lim di kampung tersebut. Kakeknya, Kiai Abdurrahman Jombor, dikenal dengan pesantren salafnya yang telah dirintisnya. Mbah Abdussomad yang makamnya sampai sekarang masih selalu diziarahi oleh masyarakat Islam Banyumas. ${ }^{14}$

\footnotetext{
13 Nasaruddin Umar, Perempuan Dalam Islam, 31.

${ }^{14}$ Masdar Farid Mas'udi, Hak-Hak Reproduksi Perempuan, 5.
} 
Setelah tamat Sekolah Dasar (SD) yang diselesaikannya selama 5 tahun, Masdar langsung diserahkan oleh ayahnya ke Pesantren salaf di Tegalrejo, Magelang, di bawah asuhan Mbah Kiai Khudlori. Tiga tahun di Tegalrejo, Masdar telah menamatkan dan menghafalkan Alfiyah Ibnu Aqil.

Selanjutnya pindah ke Pesantren Krapyak, Yogyakarta berguru kepada Mbah Kiai Ali Maksoem, Rois Am PBNU tahun 1988 - 1999. Meskipun dari Tegalrejo baru menyelesaikan pendidikan setara dengan kelas III Tsanawiyah, di Krapyak Masdar langsung diterima di kelas III Aliyah.

Tahun 1970, selesai Aliyah, Masdar dinasehati oleh Mbah Ali untuk tidak langsung ke IAIN, melainkan untuk ngajar dan menjadi asisten pribadi Kiai terutama dalam tugas-tugas beliau sebagai dosen luar biasa IAIN Sunan Kalijaga. Dalam kapasitasnya sebagai asisten pribadi inilah Masdar memperoleh kesempatan langka untuk memanfaatkan perpustakaan pribadi Mbah Ali yang berisi kitab-kitab pilihan baik yang salaf (klasik) maupun yang khalaf (modern).

Tahun 1972, sambil tetap tinggal dan mengajar di Pesantren Krapyak, Masdar melanjutkan studi di Fakultas Syariah IAIN Sunan Kalijaga, Yogyakarta, jurusan Tafsir-Hadis. Di masjid Jami' IAIN, Masdar sempat menggelar tradisi baru pengajian kitab kuning dengan mem-balah (mengajar) Alfiyah untuk kalangan mahasiswa. ${ }^{15}$

Berbagai seminar ilmiah telah diikutinya sebagai pembicara mewakili sudut pandang Islam, baik dalam maupun luar negeri. Antara lain, di Manila dan Mindanau (Philipina) di Kuala Lumpur (Malaysia), di Singapura, di Kairo (Mesir), Sidney (Australia), Belanda dan Denmark. Ia juga pernah mengadakan kunjungan di pusat-pusat keagamaan di Amerika selama 5 pekan, tahun 1986.

Di antara aktivitas organisasi Masdar F Masudi diawali ketika tahun 1972 dipilih sebagai ketua Pergerakan Mahasiswa Islam 
Indonesia (PMII) Komisariat Krapyak, Yogyakarta, sampai dengan 1974. Selanjutnya pada tahun 1976 terpilih sebagai Sekjen Dewan Mahasiswa IAIN Sunan Kalijaga Yogyakarta sampai dengan 1978. Sebagai aktivis mahasiswa, Masdar pernah ditahan oleh Penguasa Orde Baru bersama 9 tokoh aktivis mahasiswa lainnya di markas Pomdam Jawa Tengah, Semarang selama 5 bulan lebih. Penahanan tanpa peradilan itu dilakukan karena 'dosa' memimpin demo anti korupsi menjelang Sidang Umum MPR 1978. Tahun 1982, setelah hijrah di Jakarta, Masdar dipilih sebagai Ketua I Pengurus Besar PMII periode 1982-1987 mendampingi Muhyidin Arubusman sebagai Ketua Umum. Selesai kuliah, tahun 1980 Masdar hijrah ke Jakarta dan bekerja untuk Lembaga Missi Islam NU sambil menjadi wartawan di beberapa media massa ibu kota. Tahun 1985, setelah Muktamar Situbondo, bersama dengan Kiai Irfan Zidni, Masdar ditunjuk sebagai asisten Ketua Umum (Gus Dur) dan Rois Am di bidang Pengembangan Pemikiran Keagamaan. ${ }^{16}$

Sebagai kordinator program P3M (Perhimpunan Pengembangan Pesantren dan Masyarakat), Masdar sempat menerbitkan Jurnal PESANTREN, yang pertama dan satu-satunya jurnal ilmiah Islam yang terbit antara tahun 1984 - 1990. Di lain pihak, didukung oleh Rabitah Ma'ahid Islami (RMI) dibawah duet kepemimpinan (alm) KH. Imran Hamzah dan (alm) KH. Wahid Zaini, Masdar merintis berbagai kegiatan kajian khazanah keislaman Salaf melalui berbagai halaqah. Dimulai dari halaqah Watucongol tahun 1989 dengan tema "Memahami Kitab Kuning secara Kontekstual", kegiatan itu terus bergulir di berbagai daerah dengan keikutsertaan para Kiai baik yang sepuh maupun yang muda-muda. Salah satu di antara out putnya yang monumental adalah rumusan Metode Pengambilan Hukum yang menjadi keputusan Munas NU Lampung 1992. ${ }^{17}$

\footnotetext{
${ }^{16}$ Masdar Farid Mas'udi, Keadilan Risalah Zakat Pajak dalam Islam, 175.

17 Imronfauzi, Berakar Pada Tradisi Bervisi Moderen, diakses tanggal 5 September 2009 dalam http://imronfauzi.wordpress.com/2009/07/21/kh-masdar-farid-masudi/2009
}

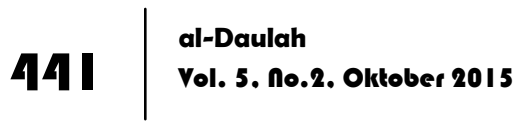


Saat ini, kegiatan sehari-harinya selain sebagai Ketua Pengurus Besar Nahdlatul Ulama (PBNU) juga sebagai Direktur Perhimpunan Pengembangan Pesantren dan Masyarakat (P3M) Jakarta, Anggota Dewan Etik ICW (Indonesian Corruption Wacth) dan Komisi Ombudsman Nasional (KON) serta membina pesantren Al-Bayan, di kampung Cikiwul, Pancoran Mas, Cibadak, Sukabumi. Dengan program pendidikan formal utamanya SMA, sudah tiga angkatan diluluskan dengan prestasi akademik yang unggul sesuai dengan namanya. Yakni rata-rata 95 persen lulusannya diterima di Perguruan Tinggi Negeri terbaik. Mulai tahun 2004 merintis cabang di Depok, Bogor, dengan program yang sama. ${ }^{18}$

\section{Karya-Karyanya}

Berbagai karya ilmiyah berupa makalah, artikel dan juga buku telah berhasil diterbitkan. Yang utama, berupa buku utuh, dan beberapa kumpulan tulisan adalah sebagai berikut:

1) Keadilan; Risalah Zakat / Pajak dalam Islam.

2) Islam dan Hak-Hak Reproduksi Perempuan.

3) Yang terakhir ini, pada tahun 2002, bahkan telah diterbitkan dalam versi Inggris berjudul "Islam \& Women's Reproductive Rights" oleh Penerbit Sisters in Islam, Kuala Lumpur, Malaysia. ${ }^{19}$

4) Menggugat Tradisi: Pergulatan Pemikiran Anak Muda NU.

5) Dinamika Kaum Santri, Penerbit CV Rajawali.

6) Peranan ombudsman dalam pemberantasan dan pencegahan korupsi serta penyelenggaraan pemerintahan yang bersih. Penerbit: Jakarta: Komisi Ombudsman Nasional.

7) Fikih Lintas Agama.

8) Agama-agama, Kekerasan dan Perdamaian.

9) NU "liberal": dari tradisionalisme ahlussunah ke universalisme Islam.

${ }^{18} \mathrm{lbid}$.

${ }^{19} \mathrm{lbid}$., 6. 
10) Fiqh : Permusyawaratan/Perwakilan Rakyat / editor, Masdar Farid Mas'udi.

\section{Metode Pemikiran Masdar Farid Mas'udi tentang Kepemimpinan Perempuan}

Adapun metodologi yang dipakai Masdar Farid Mas'udi dalam hal ini, adalah mengarah kepada pola metode kritis analisis. Metodologi ini didasarkan pada fakta-fakta berikut:

Pertama, dalam upaya penemuan hukum baru, sebagaimana Hazairin dan Munawirin, Masdar memilih metode alternatif yang dikembangkannya sendiri. Yakni rekonstruksi penafsiran. Rekonstruksi penafsiran Masdar ditempuh melalui rekonstruksi qat' ' $i$ dan d\}anni. Untuk mendukung upaya penfasiran itu, Masdar menyarankan dipakainya hermenuetika sebagai sarana bantu untuk melakukan rekontruksi interpretative, yang menurutnya lebih bisa menghasilkan penafsiran yang lebih dekat pada kebenaran dan kemaslahatan. Berdasarkan uraian demikian, maka metode yang dipakai Masdar cenderung pada pola rekontruksi interpretative. ${ }^{20}$

Kedua, hasil pemikiran hukum Masdar lebih cenderung menampakkan sisi kritis terhadap teks (fikih). Menafsirkan teks (fikih) disesuaikan dengan kondisi sosial saat sekarang ini. Dan tidak bisa dibantah bahwa pola pemikiran Masdar yang demikian itu mengarah kuat pada pola responsi kritis terhadap apa yang terjadi dengan zaman sekarang. Kalau fikih melarang perempuan di ranah publik (pemimpin negara) dan membatasi peran perempuan di ranah publik, Masdar membolehkannya. Karena menurutnya, setiap manusia baik laki-laki maupun perempuan juga berhak dalam dunia publik. Yang dimaksud aktivitas publik menurut Masdar seperti, sebagai guru, pekerja sosial,

20 Mahsun Fuad, Hukum Islam Indonesia, Dari Nalar Parsipatoris Hingga Emansipatoris, (Yogyakarta: LKiS, 2005), 250. 
kepengurusan organisasi kemasyarakatan, ahli hukum seniman, politisi, agamawan, dan sebagainya. ${ }^{21}$

Ada kaidah-yang sering dianggap sebagai kaidah syariatyang menyatakan, "Tidak bisa ditolak adanya perubahan hukum karena perubahan zaman." 22 Para mufassir feminis sering menggunakan kaidah ini dengan alasan bahwa penafsiran para mufassir sangat dipengaruhi oleh kondisi sosiologis zamannya. Adanya perubahan historis-sosiologis sampai pada era ini mengharuskan revisi penafsiran yang telah lalu. Penafsiran klasik dianggap tidak sesuai lagi dengan kondisi sosiologis masyarakat saat ini. Demikian juga dengan Masdar, menafsikan teks (fikih) mestilah dipahami secara kontekstual, dengan memperhatikan latar belakang sejarah, sosial dan politik.

Berdasarkan metodologi Masdar yang telah dipaparkan di atas, maka sebenarnya dalam Islam tidak ada yang dinamakan hak-hak perempuan atau hak-hak laki-laki. Begitu pula dalam Islam tidak ada apa yang dinamakan kewajiban perempuan dan kewajiban laki-laki. Yang ada dalam Islam tiada lain adalah hakhak dan kewajiban-kewajiban manusia dalam kedudukannya sebagai manusia, tidak melihat lagi apakah dia laki-laki atau perempuan.

Maka dari itu, berdasarkan keumuman Syariat Islam dan keumuman tiap-tiap hukum dalam Syariat Islam, maka perempuan berhak beraktivitas dalam aspek perdagangan, pertanian, dan perindustrian sebagaimana laki-laki, sebab Syariat Islam telah datang dalam seruan yang bersifat umum untuk manusia, baik laki-laki maupun perempuan. Perempuan berhak pula menjalankan seluruh tas\}arrufat qauliyah, yakni melaksanakan berbagai akad-akad dan muamalah sebab Syariat Islam datang untuk manusia, baik laki-laki maupun perempuan. Perempuan berhak pula memiliki satu sebab di antara sebab-sebab kepemilikan harta dan berhak pula untuk mengembangkan

2I Masdar Farid Mas'udi, Islam dan Hak-Hak Reproduksi Perempuan, 84.

${ }^{22}$ Abdul Hamid Hakim, Al-Bayan, 16. 
hartanya dengan cara syar'i apapun baik dikerjakan sendiri maupun dikerjakan orang lain, sebab Syariat Islam datang untuk manusia, baik laki-laki maupun perempuan. Demikian pula perempuan berhak pula melakukan kegiatan pendidikan, berjihad, melakukan kegiatan politik seperti bergabung dengan sebuah partai politik, serta melakukan segala aktivitas dalam segala aspek kehidupan sebagaimana laki-laki, sebab Syariat adalah untuk manusia, baik laki-laki maupun perempuan. ${ }^{23}$

\section{Pemikiran Masdar Farid Mas'udi tentang Kepemimpinan Politik Perempuan}

Masdar Farid Mas'udi sudah lama terkenal sebagai sosok lokomotif pembaharu dalam tubuh NU yang dikenal kritis, analitis, progresif, dan kadang kala mengagetkan. Dua bukunya, Agama Keadilan, Risalah Zakat (Pajak) Dalam Islam, dan Reproduksi Perempuan adalah salah satu bukti konsistensinya dalam lapangan pembaharuan pemikiran. ${ }^{24}$

Pemikiran Masdar inipun banyak yang menular ke bawah. Ulil Abshar Abdallah, tokoh muda NU dan lokomotif JIL dalam bukunya Membakar Rumah Tuhan menceritakan, ketika Lakpesdam NU mengadakan program pelatihan bagi para Kiai muda NU dari seluruh Jawa, ternyata, banyak dari mereka yang sudah mempunyai pemikiran progresif, semisal Kiai Husen Muhammad dari Arjawinangun, Cirebon, dan KH. Moh. Ishom Hadizq (al-maghfurlah) dari Tebuireng Jombang. Mereka sudah terbiasa dengan pikiran-pikiran Moh. Arkoun dan Fazlur Rahman.

Yang paling menonjol dari Masdar Farid Mas'udi adalah kiprahnya di bidang pemikiran keagaman yang seringkali dianggap mengagetkan. Secara garis besar pemikiran Masdar ini dapat diidentifikasi dalam sebuah kerangka paradigmatik yang disebutnya Islam al-Islam at-Taharruriy. Dari sudut visi dan akar keprihatinannya, Islam Taharruri ini memiliki karakter yang

\footnotetext{
${ }^{23}$ Taqiyuddin An Nabhani, Muqaddimah Ad Dustur, 255-257.

${ }^{24}$ Masdar Farid Mas'udi, Agama Keadilan, 8.
} 
berbeda dengan kedua gerakan yang kini banyak dibicarakan orang, yakni Islam Liberal (Islib) maupun antitesanya Islam Fundamentalis (Isfund). Bahkan Islam Taharruri ini bisa dikatakan kritik terhadap kedua wacana atau gerakan Islam tersebut.

Ketika gerakan perempuan di Indonesia muncul, pada tahun 1994 P3M (didirikan pada tahun 1983) meluncurkan program yang diberi nama "Figh Nisa". Masdar dan beberapa koleganya seperti Lies Marcoes Natsir, dan Syafiq Hasyim, di P3M (Perhimpunan Pengembangan Pesantren dan Masyarakat) menggagas program ini. Masdar, melalui hubungannya dengan para Kiai, adalah satusatunya sarjana Muslim yang mengenalkan isu perempuan ke dalam pesantren. Pada waktu itu, program ini berlangsung di sejumlah pesantren di Jawa dan Madura.

Sungguh, bagi pesantren perbincangan mengenai perempuan adalah hal baru. Lagi pula, sebagaimana disebutkan sebelumnya, jarang pesantren yang mendukung isu-isu perempuan. Masdar menggunakan terminologi yang ada di pesantren, seperti nama programnya sendiri: Figh al-Nisa. Ia mengundang tokoh penting dalam pesantren seperti ibu Nyai (istri Kiai), santri dan beberapa muballig. Pengenalan yang dilakukan Masdar mengenai isu-isu perempuan dengan mudah dapat diterima para Kiai, karena Masdar sendiri seorang Kiai. Tidak diragukan, pembahasannya mengenai isu perempuan menyeluruh. Pendekatan yang dilakukan Masdar sukses. Figh al-nisâ' kemudian berlanjut di beberapa pesantren di Jawa, Jakarta dan tempat-tempat lain..$^{25}$

Berangkat dari program figh al-Nisa' tersebut, Masdar dikenal sebagai orang yang loyal dan kritis kepada tradisi keilmuan kitab kuning. Dalam berbagai forum ia senantiasa mengambil sikap bahwa kitab, selain obyek pengajian, juga harus dijadikan obyek pengkajian studi kritis. Karena menurut Masdar, karya ulama zaman dulu mestilah dipahami secara kontekstual, dengan memperhatikan latar belakang sejarah, sosial dan politik. Kitab

${ }^{25} \mathrm{Ibid}$., 8.

\begin{tabular}{l|l}
446 & $\begin{array}{l}\text { al-Daulah } \\
\text { Vol. 5. no.2. Olktober } 2015\end{array}$
\end{tabular} 
kuning dengan segala muatannya bukanlah kebenaran mutlak, melainkan juga mencerminkan budaya, kebutuhan dan pendapat umum pada tempat dan zaman yang dikarangnya. ${ }^{26}$ Oleh karena itu, apa yang dilakukan Masdar adalah untuk melakukan sebuah penafsiran kembali terhadap konsep-konsep fikih yang bias patriarkhis.

Melakukan penafsiran (reinterpretasi) terhadap fikih menurut Achmad Satori Ismail, boleh-boleh saja dilakukan asalkan masih termasuk di dalam ruang lingkup hukum-hukum hasil istimbat\} ijtihadi. Sedangkan hukum-hukum yang termasuk dalam syariat Islamiyah tidak mungkin akan diubah. ${ }^{27}$ Dengan kata lain, yang boleh direkonstruksi adalah fikih yang dikategorikan sebagai ajaran-ajaran juziyah (partikular atau teknis-oprasional) berkaitan dengan waktu dan tempat, dan yang dianggap z\}anni. Yang tidak boleh ditafsir ulang adalah ajaran yang tidak dipengaruhi waktu dan zaman, dan dianggap qat\}'i..$^{28}$

Di dalam khazanah fikih, Masdar Farid Mas'udi menjelaskan tentang kepemimpinan politik perempuan terjadi karena ada dua hal. Pertama, karena prinsip-prinsip dasar tentang kesetaraan harus dijabarkan bukan di ruang hampa sebagaimana fikih cenderung memperlakukan hukum dan ketentuan Islam, melainkan hal tersebut harus dijabarkan dalam bentuk sosial dan historis tertentu. Kedua, kecenderungan bias pandangan yang patriarkhis di dalam khazanah teks dan pemahaman keagamaan yang selama ini lebih didominasi oleh otoritas keagamaan laki-laki. ${ }^{29}$

Perdebatan wacana mengenai perempuan yang sekarang terjadi di kalangan umat Islam pada umumnya adalah debat tentang perlu dan tidaknya sebuah proses penafsiran ulang terhadap konsep fikih yang dipandang mengurangi bagi kaum

\footnotetext{
${ }^{26}$ Martin Van Brunessen, Kitab Kuning dan Perempuan, Perempuan dan Kitab Kuning, Makalah, 2.

${ }^{27}$ Robin L. Bush, Wacana Perempuaan di Lingkungan NU Sebuah Perdebatan Mencari Bentuk, Taswirul Afkar, Edisi 5, 31.

${ }^{28}$ Ibid., 31 .

${ }^{29}$ Amalia Fauziah, Tentang Perempuan Islam: Wacana Gerakan, (Jakarta: Gramidia, 2000), I 14.
} 
perempuan. Masdar berpandangan bahwa fikih (kitab kuning) yang secara umum diikuti oleh kaum pesantren "tradsional" menggambarkan perempuan sebagai makhluk yang separoh harganya dibandingkan dengan laki-laki. Dengan seperti fikih yang mengajarkan orang tua untuk membeli dua ekor kambing pada kelahiran anak laki-laki, tapi hanya satu ekor kambing pada kelahiran anak perempuan. Menurut Masdar, ajaran seperti ini sebetulnya melawan salah-satu prinsip utama dalam syari'ah, yaitu keadilan dan kesetaraan manusia, baik laki-laki maupun perempuan. Perinsip ini terlihat misalnya di dalam al-Qur' an surat an-Nahl: 97 yang artinya: "Barangsiapa yang mengerjakan amal saleh, baik laki-laki maupun perempuan dalam keadaan beriman. Maka Sesungguhnya akan kami berikan kepadanya kehidupan yang baik. Sesungguhnya akan kami beri balasan kepada mereka dengan pahala yang lebih baik dari apa yang telah mereka kerjakan".

Masalah kepemimpinan perempuan memang sudah ada sejak zaman dahulu, Masdar berpendapat, tidak mempersoalkan juga tidak benar, dari dulu di NU sendiri sudah dibicarakan, cuma NU melalui Munas NTB tahun 1987 mengambil pandangan yang moderat dan tidak dikotomis antara laki-laki dan perempuan, yang penting adalah kemampuan dan daya terimanya pemimpin itu. Kalau masyarakat menganggap si $\mathrm{A}$ mampu, walau dia berkelamin laki-laki atau perempuan, yang penting ia mampu." 30

Sebenarnya saat sekarang ini, tidak sedikit kaum perempuan yang memiliki standar keilmuan seperti kaum pria. Dan idealnya tidak hanya kaum laki-laki yang berhak menempati posisi publik, perempuan juga mempunyai hak. Jadi menurut Masdar tidak ada larangan dan batasan bagi perempuan untuk berkreativitas di ranah publik.

30 Choirul Anam, Masjid Masdar: Kita Perlu Silaturrahmi Hadapi Masalah Khilafiyah, Sabtu, 5 Juni,http://www.nu.or.id/page.php?lang=id\&menu=news_view\&news_id=3101, 2004. 


\section{Konsep Kepemimpinan Perempuan menurut Kiai Husen Muhammad}

\section{Riwayat Hidup dan Pendidikan}

Kiai Husen Muhammad, adalah putra pasangan Nyai Ummu Salma Shathori dan KH Muhammad Asyrofuddin. Lahir di Cirebon, tepatnya di Pondok Pesantren Dar at Tauhid Arjawinangun Cirebon pada tanggal 9 Mei 1953. Nasab Kiai diperoleh dari ibunya yang merupakan putri pendiri pesantren tersebut yaitu KH Syathori, sedangkan ayahnya hanyalah orang biasa yang diambil menantu oleh KH Syathori. Akan tetapi walaupun orang biasa Kiai Muhammad Asyrofuddin juga merupakan keturunan keluarga yang biasa mengenyam pendidikan pesantren. Sehingga secara kultural Husen Muhammad lahir dan tumbuh dari keluarga pesantren. ${ }^{31}$

Saudara kandung Kiai Husen Muhammad berjumlah delapan orang, yaitu:

1) Hasan Thuba Muhammad, pengasuh Pesantren Raudlah atThalibin Bojonegoro Jawa Timur.

2) Kiai Husen Muhammad, pengasuh Pesantren Dar at -Tauhid Cerebon.

3) Dr. Ahsin Sakho Muhammad, pengasuh Pesantren Dar atTauhid Cerebon.

4) Ubaidah Muhammad, pengasuh Pesantren Lasem Jawa Tengah.

5) Mahsun Muhammad, pengasuh Pesantren Dar at-Tauhid Cirebon.

6) Azza Nur Laila, pengasuh pesantren HMQ Lirboyo Kediri.

7) Salman Muhammad, pengasuh Pesantren Tambak Beras Jombang Jawa Timur.

8) Faiqoh Muhammad, pengasuh pesantren Langitan Tuban Jawa Timur. ${ }^{32}$

${ }^{31}$ Nuruzzaman, Kiai Husen Membela Perempuan, (Yogyakarta: LKiS, 2005), I 01.

32 Ibid., 102. 
Semua saudara Kiai Husen Muhammad yang menjadi pengasuh di banyak pesantren menunjukkan bahwa mereka merupakan keturunan keluarga yang peduli terhadap pendidikan. Hal ini bisa dilihat dari figur kakek mereka KH Syathori yang giat memperjuangkan pendidikan dengan menggunakan sistem pendidikan madrasah, padahal pada waktu itu sistem pendidikan madrasah belum banyak digunakan oleh pesantren.

Kiai Husen Muhammad mengenyam pendidikan baik pendidikan agama yang merupakan kultur keluarganya dan juga pendidikan umum. Pendidikan agama mula-mula dia peroleh dari kakeknya KH Syathori, dan juga madrasah diniyah (agama). Di samping itu Husen juga bersekolah di Sekolah Dasar, selesai tahun 1966, kemudian melanjutkan di Sekolah Menengah Pertama Negeri (SMPN) 1 Arjawinangun selesai tahun 1969. Ketika menjalani pendidikan di SMP, banyak hal dilakukan oleh Husen Muhammad, dia aktif dalam organisasi sekolah bersama rekanrekannya.

Kiai Husen menikah dengan seorang gadis yang bernama Lilik Nihayah Fuady Amin. Dari hasil pernikahannya telah dikarunia lima orang anak yakni: Hilya Aulia (1991), Layali Hilwa (1992), Muhammad Fayyaz Mumtaz (1994), Najlah Hammadah (2002), dan Fazla Muhammad (2003).33

Husen Muhammad belajar agama sejak kecil di pesantren. Ia pertama kali belajar Al-Qur'an pada Kiai Mahmud Toha dan pada kakeknya sendiri Kiai Syatori. Di samping belajar di Madrasah Diniyah (sekolah agama) pesantren, Kiai Husen juga belajar di SD (sekolah dasar) dan selesai tahun 1966. kemudian melanjutkan di SMPN (sekolah menegah pertama negeri) Arjawinangun dan selesai tahun 1969, di SMPN inilah ia mulai aktif dalam organisasi sekolah bersama rekan se-almamater. Hal ini menunjukkan bahwa lingkungan pesantren Husen telah memberikan ruang yang kondusif untuk kemajuan dengan membolehkan anak-anak Kiai

33 Ibid., 103.

\begin{tabular}{l|l}
450 & $\begin{array}{l}\text { al-Daulah } \\
\text { Vol. 5. no.2. Olktober } 2015\end{array}$
\end{tabular} 
menempuh pendidikan umum yang pada masa itu hal tersebut sangat dilarang para Kiai di pesantren. Usai menamatkan SMPN Husen melanjutkan belajar di Pondok Pesantren Lirboyo, Kediri, sampai pada tahun 1973. ${ }^{34}$

Tiga tahun di Pondok Pesantren Lirboyo, Kiai Husen melanjutkan pendidikannya ke Perguruan Tinggi Ilmu Al-Qur'an (PTIQ) tahun 1975 di Jakarta. Perguruan tinggi ini mengkhususkan kajian tentang Al-Qur'an dan mewajibkan mahasiswanya untuk hafal Al-Qur'an, Kiai Husen menyelesaikan pendidikannya di PTIQ. Husen sangat aktif dalam kegiatan-kegiatan mahasiswa baik ekstra maupun intra kampus. Husen bersama rekannya mempelopori adanya majalah dinding di kampus dalam bentuk tulisan reportase. Keakraban Husen dengan jurnalistik ini karena ia pernah mengikuti pendidikan jurnalistik dengan mustafa Hilmy, orang yang pernah menjadi redaktur Tempo. Husen bersama teman-temannya juga melahirkan PMII kebayoran lama. ${ }^{35}$

Kiai Husen Muhammad menyelesaikan pendidikan formalnnya di PTIQ pada tahun 1980, kemudian melanjutkan studinya ke Al-Azhar Mesir sampai tahun 1983. ${ }^{36}$ Ia tidak bisa menjadi mahasiswa pasca sarjana di Universitas terbesar di Timur Tengah tersebut, karena ijazah sarjana PTIQ belum disamakan. Sekalipun begitu, niatnya untuk menuntut ilmu tidak surut. Akhirnya ia belajar pada sejumlah Syeikh (guru besar) secara privat di Majma, Al-Buhu Al-Isla-miyah milik Al-Azhar. Secara formal di Al-Azhar ia belajar di Dira-sah Khasasah (Arabic Special Studies). ${ }^{37}$

Husen Muhammad mengambil ilmu tafsir sesuai dengan saran gurunya di PTIQ yaitu Prof. Ibrahim Husen, karena Mesir lebih terbuka dalam bidang tafsir dibandingkan dengan negara Timur Tengah lainnya. Selama di Kairo, Kiai Husen Muhammad

\footnotetext{
${ }^{34}$ Nuruzzaman, Kiai Husen Membela Perempuan, I I 2.

35 Ibid., I I3.

${ }^{36}$ Ala'i Nadjib, Feminis Muslim Indonesia, 39.

${ }^{37}$ Nuruzzaman, Kiai Husen Membela perempuan, I I 4.
} 
tidak menyiakan kesempatan untuk membaca kitab-kitab yang tidak ia jumpai di Indonesia seperti karya Qasim Amin, Ahmad Amin dan buku-buku filsafat karya pemikir Negara barat seperti karya Nietche, Sartre dan lain-lain. Kiai Husen belajar di Mesir selama tiga tahun dan tahun 1983 pulang ke Indonesia. ${ }^{38}$ Sejak saat itu, dia mengabdi di pesantren Dar al-Tauhid Cirebon Jawa barat untuk mengembankan pesantren kakeknya sampai sekarang.

\section{Karya-Karyanya}

Sebagai intilektual muda yang memiliki kemampuan dalam bidang jurnalistik dan mempunyai kemampuan dalam berbahasa Arab, maka ia telah membuat dan menerbitkan buku serta menerjemahkan buku-buku ke dalam bahasa Indonesia. Dengan kemampuannya itu, ia cukup produktif dalam menulis maupun menerjemahkan buku. Secara umum karya-karya Kiai Husen Muhammad dibagi menjadi dua bagian yaitu:

Karya tulis Ilmiah:

a. "Metodologi Kajian Kitab Kuning" Pesantren Masa Depan" Pustaka Hidayah, Bandung 1999.

b. Fiqih Perempuan, Refleksi Kiai Atas wacana dan Gender, Yogyakarta: LkiS, 2001.

c. Gender di Pesantren (Pesantren and the Issue of Gender Relation), dalam majalah Kultur (The Indonesia Journal for muslim Cultures), Centr for Languages and Cultures, UIN Syarif Hidayatullah, Jakarta, 2002.

d. Memahami Sejarah yang Toleran dan Anti Akstrim, Moderasi Imam Syafi'I dalam majalah Aula (edisi Juli dan Agustus 1997).

e. "Taransformasi Paradigma Bahtsul Masail" LAKPESDAM, Jakarta, 2002.

f. "Kelemahan dan Fitnah Perempuan" dalam Moqsith Ghazali, et.all Tubuh, Seksualitas dan Kedaulatan Perempuan. Bunga

${ }^{38}$ Ibid., I 15. 
Ramapai Pemikiran Ulama Muda, Rahima-FF-LkiS, Yogyakarta, 2002.

g. "Kebudayaan yang Timpang", dalam K.M. Ikhsanuddin, dkk, Panduan pengajaran Fiqh Perempuan di Pesantren, YKF-FF, Yogyakarta, 2002.

h. Dalam Jurnal Taswirul Afkar Lakpesdam. Diantaranya: "Tradisi Istimabath Hukum NU: sebuah Kritik" (1999), "Kitab Mu'tabar dan Ghayr Mu'tabar Versus Arus Leberatif Generasi Baru NU" (2004), "Akar-Akar Teologi Rekontruksi dalam Islam" (2003), "Kajian Atas Kitab Uqud al-Lujain: Sebuah Analisis" (1999).

i. Islam Agama Ramah Perempuan: Pembebasan Kiai Pesantren (Yogyakarta. LKiS, 2004).

j. Pemikir Fiqh yang Arif dalam K.H. MA. Sahal Mahfudh, Wajah Baru Fiqh Pesantren, Citra Pustaka, Jakarta 2004.

k. Potret Penindasan atas nama Hasrat dalam Soffa Ihsan, In the Name of Sex: Santri, dunia kelamin, dan Kitab Kuning, JP. Books, Surabay, 2004.

1. Kembang Setaman Perkawinan: Analisis Kritis Kitab Uqud alLujain FK-3 Bekerjasama dengan KOMPAS Jakarta 2005.

m. Draft: Ikhtiar Pembaruan Hukum Keluarga Islam, PSW Purwekwerto kerjasama dengan Unggun Religi, Yogyakarta 2005.

n. Sebaiknya memang tidak Poligami, dalam pengantar buku, Memilih Monogami" (2005).

o. Spritualitas kemanusiaan, Pustaka Rihlah group, Yogyakarta, 2006.

p. Wajah Perempuan dan Hak-Hak Refroduksinya dalam AlQur'an, dalam Jurnal "MAWADDAH" Fak. Syari'ah UIN Sunan Kalijaga, 2006.

q. Conter Legal draft: Merespon Realitas Sosial Baru dalam Ridwan, M.Ag, Kontroversi Counter Legal.

r. Islam Progresif: Refleksi Kritis Kiai Pesantren terhadap wacana Kemanusiaan, Pustaka Rihlah Group, Yogyakarta. 
s. Kebudayaan yhang Timpang, sebuah epilog dalam buku panduan pengajaran fikih Perempuaan. ${ }^{39}$

t. Membongkar Konsepsi Fiqh Perempuaan, dalam Syafiq Hasyim Hisyam, " Kepemimpinan Perempuan dalam Islam". ${ }^{40}$

u. Sejumlah makalah seminar/diskusi, antara lain: "Islam dan Negara Bangsa", "Pesantren dan Civil Soceity", dan "Islam dan Hak-Hak Refroduksi.

\section{Karya Terjemahan:}

a. Khutbah al-Jumu'ah Wa Al-Idain, Lajnah Min Kibar Ulama, Al-Azhar (wasiat taqwa ulama-ulama besar), (Kairo: Bulan Bintang, 1985).

b. Asy-syari'ah Al-Islamiyah bain Al-Mujahidin wa AlMuhaddistin, (hukum Islam antara modernis dan tradisionalis), karya Dr. Faruq Abu Zaid, (Jakarta: P3M, 1986.

c. Muwathin fi asy-syari'ah al-islamiyah karangan syaikh Mauhammad al-Madani, at-taqlid wa at-talfiqh al-islamiyah karangan sayyid $\mathrm{Mu}^{\prime}$ in Ad-din, ali-ijtihad wa at-taqlid baina addhawabith asy-sya'iyyah wa al-hayah al-mu'ashirah (dasardasar pemikiran hukum islam) karangan Dr. Yusuf Qardawi (jakarta: Pustaka Fisdaus, 1987).

d. Kasyifah As-saja', (Bandung: 1992).

e. Thabaqat al-Ushuliyyin (pakar-pakar Fiqh Sepanjang Sejarah) karangan Syaikh Mustafa Al-Maraghi (Yogyakarta: LKPSM, 2001).

f. Wajah baru kiatab syarh uqud al-hujain, karya bersama forum kajian kitab kuning jakarta, (Yogyakarta: LkiS, 2001). ${ }^{41}$

Kiai Husen Muhammad juga memiliki pengalaman organisasi dan aktivitas yang sangat panjang, mulai dari aktivitas kampus ketika ia masih menjadi mahasiswa di PTIQ Jakarta (Perguruan

\footnotetext{
39 Nuruzzaman, Kiai Husen Membela Perempuan, 121.

${ }^{40}$ Ala'i, Feminis Muslim Indonesia, 39.

${ }^{41}$ Ibid., |21-122.
} 
Tinggi Ilmu Al-Qur'an), sampai menjadi di beberapa LSM Perempuan, Kepala Sekolah, dan juga Aktivis Partai Politik. Ia juga salah satu wakil Ketua DPRD Cirebon.

Di antara aktivitas organisasi Kiai Husen Muhammad bisa adalah sebagai berikut:

1. Ketua I Dewan Mahasiswa PTIQ Tahun 1979.

2. Ketua I Perwakilan Cabang Indonesia keluarga Mahasiswa Nahdlatul Ulama (PCI-KMNU Kairo Mesir, 1982-1979.

3. Sekretaris Perhimpunan Cabang Indoneisia keluarga Mahasiswa Nahdlatul Ulama (PC-KMNU) Kairo Mesir, 19821979.

4. Pendiri Fahmina Institute, Cirebon.

5. Pengasuh Ponpes Dar At-Tauhid yang ada di Daerah Arjawinangun, Cerbon.

6. Anggota Dewan Shoro DPP PKB 2001-2005.

7. Ketua Dewan Tanfidz PKB Kabupaten Ceribon, 1999sekarang.

8. Wakil Ketua DPRD Kabupaten Ceribon, 1999-sekarang.

9. Ketua Umum Yayasan wali Sanga, 1996-sekarang.

10. Ketua I Yayasan Pesantren Dar At-Tauhid, 1984-1999.

11. Wakil Rais Syuriah NU Cabang Kab. Cirebon, 1989-2001.

12. Sekjen RMI Jawa Barat, 1994-1999.

13. Pengurus PP RMI 1989-1999.

14. Wakil Pengurus Yayasan Puan Amal hayati, Jakrta, 1999sekarang.

15. Direktur Pengembangan Wacana LSM Rahimah, Jakarta, 2000-sekarang.

16. Ketua Umum DKM Masjid Jami' Fadhlullah, Arjawinangun, 1989-sekarang.

17. Kepala Madrasah Aliayah Nusantara Berlokasi di Arjawinangun, 1989-sekarang.

18. Kepala SMU Ma'arif, Arjawinagun, 2001.

19. Ketua Kepontren Dar at-tauhid, 1994-sekarang. 
20. Ketua Departemin Kajian Filsafat dan pemikiran ICMI ORSAT Kabupaten Cirebon, 1994-2000.

21. Pemimpin Umum Dwi Bulanan "Swara Rahimah", Jakarta, 2001.

22. Dewan RedaksiJurnal Dwi Baulanan "Puan Amal Hayati", Jakarta, 2001.

23. Konsultan Yayasan balqis untuk hak-hak perempuan, Cirebon, 2002.

24. Konsultan/staf ahli Kajian Fiqh siyasah dan perempuan.

25. Pendiri LSM Puan Amal Hayati Ceribon.

26. Anggota Nasional Broad of International Center for Islam and Pluralism, Jakarta, 2003.

27. Tim Pakar Indoneisia Forum of Parlentarians On Population and Develoment, 2003.

28. Dewan Penasehat dan Pendiri KPPI (Koalisi Perempuan Partai Politik Indoneisia) di Kabupaten Cirebon, 2004. ${ }^{42}$

Dengan aktivitasnya yang begitu penting di berbagai organisasi maka tidak sedikit kegiatannya di seminar yang berkala nasional maupun internasional. Adapun keterlibatannya dalam beberapa konferensi dan seminar internasional:

a. Mengikuti konfrensi internasional tentang "Al-Quran da IPTEK", yang diselenggarakan Rabithah Alam Islami di Bandung pada tahun 1996.

b. Peserta konferensi internasional tentang "kependudukan dan Kesehatan Refroduksi", di Kairro tahun 1998.

c. Peserta seminar internasional tentang AIDS di Kuala Lumpur Malaysia 1999.

d. Mengikuti studi banding di Turki, 6-13 Juli 2002 tentang aborsi amtan.

e. Fellowship pada Institute Studi Islam Modern (ISIM) Universitas Leiden, Belanda November 2002. 
f. Nara sumber dan lokakarya internasional: Islam dan Gender, di Clombo, Srilanka, 2003.43

\section{Metode Pemikiran Kiai Husen Muhammad tentang Kepemimpinan Perempuan}

Metodologi dalam kajian keilmuan merupakan dasar utama untuk mengetahui validitas dan akurasi hasil kajian. Dengan demikian, untuk mengetahui metode pemikiran Kiai Husen Muhammad tentang konsep kepemimpinan perempuan, yaitu menggunakan metode kritis. Metode ini terdiri dari dua pendekatan yang saling kait mengkait. Pertama, pendekatan kritik sejarah pemikiran, dan kedua penafsiran al-Qur'an secara sistematis.

Berikut ini metode tersebut akan dibahas dan dianalisis sehingga konsistensi antara metode dan pandangan-pandangan Kiai Husen Muhammad dapat ditangkap secara utuh dan jelas. Pada gilirannya, melalui pemahaman terhadap metodologi yang digunakan Kiai Husen, akan diketahui persamaan dan kelemahan konsep-konsep yang ditawarkannya.

Kepemimpinan perempuan dalam analisis Kiai Husen Muhammad merupakan gerakan pertama yang dikenal dalam sejarah, yang memandang masyarakat secara serius dan menganggap sejarah itu dengan penuh arti. Sebagaimana yang telah dicontohkan sejarah perempuan pada masa Nabi dahulu. Sejarah kenabian mencatat sejumlah besar perempuan yang ikut memainkan perannya sebagaimana kaum laki-laki seperti, Khadijah, Aisyah, Um Salamah, Fatimah, Zainab, dan perempuan terkemuka yang lain. Mereka- mereka sering terlibat dalam tematema sosial dan politik bahkan mengkritik kebijakan-kebijakan domestik maupun publik.

${ }^{43}$ Ibid., 125; dan data ini diperoleh dari hasil penlitiannya Qoidud Duwal, Mahasiswa Fakultas Syari'ah Jurusan Al-Ahwal Al-Ayakhsiyyah Universitas Islam Negeri Sunan Kali Jaga Yogyakarta, Konsep Jilbab Dalam Hukum Islam (Studi Pemikiran Kiai Husen Muhammad), 2009, 62-67.

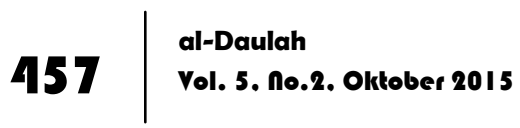


Selain menggunakan metode kritik sejarah, Kiai Husen juga menggunakan penafsiran al-Qur'an secara sistematis. Dalam pandangannya Kiai Husen mencoba menggunakan metode penafsiran yang dikemukakan oleh Fazlur Rahman. Dia menganjurkan agar semua ayat al-Qur'an, yang diturunkan sebagaimana adanya pada waktu tertentu dalam sejarah dan dalam suasana umum dan khusus, diungkapkan menurut suasana tersebut.

Argumentasi yang dipakai Kiai Husen tetap berlandaskan dengan al-Qur'an dan hadits, yang sahih juga berpendirian pada ulama klasik yang menurutnya telah menginterpretasikan teks alQur'an dan hadits secara tepat. Rujukan Kiai Husen tetap dan selalu berlandaskan tradisi kitab kuning yang menjadi rujukan masyarakat pesantren dalam pengambilan hukumnya mengenai peran politik perempuan.

Adapun yang menjadi rujukan Kiai Husen adalah sebagai berikut: Tafsir Ibnu Kasir, Tafsir Al-Munir, Ahkam Al-Qur'an alTabaqat, Muhtar As-Sihah, Bidayatul Mujtahid Syarah al-Bidayah, Fath al-Qadir, al-Mugni, al-Majmu Sarh al-Muhazzab, Sahih Muslim, Sahih Bukhhori, Sunan Tirmidzi, dan kitab-kitab lainnya.

Dengan demikian, dalam metodologi yang digunakan Kiai Husen Muhammad ada hal-hal yang sangat spesifik dalam agama/teks-teks keagamaan, yaitu kontekstual tidak bisa berlaku abadi di mana saja dan kapan saja. Yang tidak berubah dari ruang dan waktu, di mana dan kapan saja adalah norma keadilan atau subtansi agamanya, yaitu keadilan. ${ }^{4}$

\section{Pemikiran Kiai Husen Muhammad tentang Kepemimpinan Perempuan}

Masalah kepemimpinan perempuan, adalah sebuah persoalan yang paling "aktual" untuk terus diperbincangkan. Persoalan ini sempat menjadi tema pada acara bahtsul masail di Muktamar NU

\footnotetext{
${ }^{44}$ Nuruzzaman, Kiai Husen Membela Perempuan, 177.
} 
di Lombok pada tahun 1997. Waktu itu Kiai Nur Muhammad Iskandar dengan tegas menolak seorang perempuan menjadi presiden, sedangkan Masdar Farid Mas'udi tidak menemukan alasan atau dalil agama yang menolak hak perempuan untuk menjadi presiden. Akan tetapi, karena ada perbedaan pendapat, deklarasi NU mengenai peran publik perempuan tidak membuat pernyataan yang jelas dan tegas mengenai hal itu. Dan menariknya, ketua NU KH. Abdurrahman Wahid yang panggilan akrabnya Gus Dur, dalam pernyataannya kepada pers, mendukung ide bahwa perempuan dapat menjadi presiden. ${ }^{45}$

Selain dari pernyataan Gus Dur, Kiai Husen Muhammad juga memberikan sumbangan pemikiran tentang kepemimpinan perempuan. Menurut Kiai Husen Muhammad, bahwa segala sesuatu tergantung pada zaman, pada konteks sosiologis, dari dulu sampai sekarang, dari abad-ke abad, dan dari tahun ke tahun. Yang dicari oleh Kiai Husen adalah "esensi" ajaran agama, "subtansi" dan prinsip-prinsip yang mesti dipegang teguh, termasuk prinsip kesetaraan gender juga tercantum dalam alQur'an.

Manusia adalah Khalifah Tuhan di muka bumi. Tugasnya memakmurkan bumi untuk kesejahteraan manusia. Seperti yang telah disebutkan dalam al-Qur'an surat Al-Baqarah ayat 30 yang artinya: "Ingatlah ketika Tuhanmu berfirman kepada para malaikat: "Sesungguhnya Aku hendak menjadikan seorang khalifah di muka bumi." mereka berkata: "Mengapa Engkau hendak menjadikan (khalifah) di bumi itu orang yang akan membuat kerusakan padanya dan menumpahkan darah, padahal kami senantiasa bertasbih dengan memuji Engkau dan mensucikan Engkau?" Tuhan berfirman: "Sesungguhnya Aku mengetahui apa yang tidak kamu ketahui." 46

Teks-teks suci tersebut mengisyaratkan keharusan manusia untuk berpolitik, termasuk perempuan. Al-Qurtubi mengatakan

\footnotetext{
45 Andree Feillard, dalam pengantar buku "Figh Perempun Refleksi Kiai atas wacana Agamadan Gender". la adalah peneliti NU dari Belanda.

${ }^{46}$ Al-Qur'an, Surat Al-Baqrah, Jus I, ayat 30.
} 
bahwa ayat dalam surat al-Baqarah ini menunjukkan keharusan manusia mengangkat pemimpin pemerintahan untuk mengatur tata kehidupan masyarakat, menegakkan hukum dengan benar dan mewujudkan keadilan serta hal-hal penting lain yang diperlukan bagi kehidupan bersama. Ini semua merupakan urusan-urusan politik. ${ }^{47}$

Fakta sejarah mencatatnya, pada masa Nabi sejumlah besar perempuan yang ikut memainkan peran-peran politiknya seperti Khadijah, Aisyah, Ummi Salamah, dan istri Nabi yang lain, Fatimah (anak), Zainab (cucu), Sukaimah (cicit). Mereka-mereka adalah perempuan-perempuan yang cerdas dan mampu berada pada wilayah tersebut. Selain istri dan anak Nabi, juga sahabatnya seperti Nausaibah bin Ka'ab, Ummu Athiyah al-Anshariyyah dan Rabint al-Mu'awadz ikut bersama laki-laki dalam perjuangan bersenjata melawan penindasan dan ketidakadilan. Umar bin Khattab juga pernah mengangkat al-Syifah, seorang perempuan cerdas dan terpercaya, untuk jabatan manajer pasar di Madinah. ${ }^{48}$

Namun dalam perjalanan sejarah kepemimpinan perempuan mengalami proses degradasi dan reduksi secara besar-besaran. Ruang aktivitas perempuan dibatasi hanya pada wilayah domestik saja dan posisi secara subordinat. Pembatasan-pembatasan ini menurut Kiai Husen Muhammad bukan hanya terbaca dalam buku-buku pelajaran, tetapi juga muncul dalam realitas sosial ini.

Kenyataan pandangan diskriminatif terhadap perempuan di atas dapat kita baca dalam kitab-kitab tafsir klasik, bahkan juga sejumlah tafsir kontemporer. Di sana kita temukan dengan mudah bagaimana perempuan secara teo-kosmologis diposisikan sebagai makhluk Tuhan kelas dua. Dalam soal penciptaan manusia misalnya Adam, menurut banyak tafsir adalah manusia pertama yang diciptakan dan Hawa diciptakan dari Adam. Meskipun pernyataan tegas dari al-Qur'an sendiri tentang hal ini sesungguhnya tidak pernah ditemukan, tetapi para mufassir

${ }^{47}$ Khofifah Indar Parawansa, Hambatan Terhadap Partisipasi Politik Perempuan di Indonesia, 41.

${ }^{48}$ Husen Muhammad, Islam Agama Ramah Perempuan Pembelaan Kiai Pesantren, I66- 167. 
seperti al-Thabari, Ibnu Katsir, al-Qurtubi, dan As-Suyuti menyepakati tafsir ini. ${ }^{49}$

Tafsir teo-kosmologis ini Kiai Husen mengemukakan, menjadi basis utama bagi sobordinat dan diskriminasi perempuan untuk pandangan tafsir atas teks-teks yang lain. Ia menjadi basis bagi sejumlah pandangan keagamaan yang menyudutkan perempuan. Perempuan kemudian menjadi sumber "fitnah", akal dan agama perempuan lebih rendah (naqishat aqlin wa dinin) dan perempuan adalah makhluk lemah. Tema-tema ini dalam pandangan para penafsir al-Qur'an tradisional dalam banyak aspek terutama aspek fiqh, kemudian menjadi dasar argumen bagi peminggiran terhadap perempuaan. Aktivitas mereka dibatasi pada ruang-ruang yang sempit di dalam rumah..$^{50}$

Kesadaran Kiai Husen Muhammad terhadap adanya penindasan terhadap perempuan muncul ketika dia pada tahun 1993 diundang dalam acara seminar tentang perempuan dalam pandangan agama-agama. ${ }^{51}$ Sejak itu Husen mengetahui ada masalah besar yang dihadapi dan dialami perempuan. Dalam kurun waktu yang panjang, kaum perempuan mengalami penindasan dan sering diekspolitasi bahkan harga dirinya diperjualbelikan.

Dari fakta sejara inilah, Kiai Husen Muhammad telah memberikan gagasan-gagasan baru khususnya pembelaannya terhadap permpuan. Pembelaannya terhadap perempuan sangatlah strategis bagi pembangunan manusia. Banyak orang beranggapan bahwa masalah yang dialami dan dihadapi perempuan adalah masalah yang tidak besar. Padahal masalah

\footnotetext{
${ }^{49}$ Ibnu Jarir al-Thabari dalam, al-Jami al-Bayan'an Ta'wi Aay al-Qur'an, jus I, Ibnu Katsir, Tafsir alQur'an al-'Azhim, al-Qurtubi,Al-Jami li Ahkami al-Qur'an,juz V, h. 2, al-Suyuthi, Al-Durra alMantsur al-Tafsir bi al-Ma'tsur, juz II, II 6.

${ }^{50}$ Husen Muhammad, Tafsir Gender dalam Pemikiran Islam Kontemporer, I03- 105.

${ }^{51}$ Halaqah/seminar yang mengubah $\mathrm{KH}$. Husen Muhammad untuk merenungi masalah yang terjadi, ini, diselenggarakan pada tahun 1993 yang oleh P3M. Masdar adalah direkturnya, dan ia selalu mengajak Husen Muhammad untuk merealitaskan agama. Seperti yang telah diakui oleh Husen Muhammad bahwa Masdar adalah orang pertama yang mengenalkan gagasan-gagasan keagamaan kritis, termasuk masalah subordinasi teks agama terhadap perempuan.
} 
yang dialami dan dihadapi perempuan (ketidakadilan dan sobordinasi) adalah masalah besar, karena perempuan adalah bagian dari manusia dan bagian dari jenis manusia. Ketika perempuan dijadikan nomor dua, maka ini sebenarnya adalah masalah besar bagi kemanusiaan.

Demikian secara keseluruhan gagasan Kiai Husen Muhammad dan pandangannya tentang kepemimpinan perempuan. Dengan gagasanya ini, diharapkan mengubah paradigma masyarakat pesantren terhadap posisi perempuan, yang selama ini tersubordinasi dan termarjinalkan. Gerakan dan gagasan tentang kesetaraan terhadap perempuan yang dilakukan Kiai Husen sungguh luar biasa dan benar-benar bermakna positif. Oleh karena itu, tidak salah kalau Kiai Husen dikategorikan sebagai seorang feminis. Perjuangan Kiai Husen tentang kesetaraan, terlihat sangat bermakna, apabilah dilihat dari sisi subordinasi perempuan di masyarakat pesantren yang ada di bawah budaya patriarki.

Persamaan dan Perbedaan Pandangan Masdar Farid Mas'udi dan Kiai Husen Muhammad tentang Kepemimpinan Perempuan

Persamaan dan perbedaan antara pandangan dan pemikiran Masdar Farid Mas'udi dan Kiai Husen Muhammad tentang kepemimpinan perempuan. Tentang persamaan dan perbedaan pandangan keduanya ini, penulis jelaskan sebagaimana berikut ini:

1. Persamaan

Ada beberapa catatan yang menjelaskan letak persamaan pandangan dan pemikiran antara Masdar Farid Mas'udi dan Kiai Husen Muhammad tentang kepemimpinan perempuan, di antaranya:

Pertama, baik Masdar maupun Kiai Husen Muhammad, sama-sama berpandangan bahwa kepemimpinan perempuan tidak bertentangan dengan Islam. Bahkan, dalam pandangan keduanya ditemukan suatu paparan pemahaman, bahwa kepemimpinan 
perempuan merupakan suatu hal yang harus ditegakkan sebagai wujud tegaknya hak-hak manusia.

Hal ini bisa dilihat misalnya pada pandangan Masdar yang mempertanyakan dasar dan dalil yang digunakan kelompok yang mengharamkan perempuan menjadi pemimpin. Dalam pandangannya, anggapan tentang wacana agama tidak membolehkan perempuan menjadi pemimpin karena semata-mata mereka berkelamin perempuan haruslah ditinjau kembali. Menurutnya, kepemimpinan bisa dipegang siapa saja asalkan ia mampu. ${ }^{52}$

Begitu pula dengan Kiai Husen Muhammad yang menjelaskan, bahwa penafsiran terhadap nash-nash gender yang mendiskriminasi kaum perempuan haruslah direnovasi sesuai dengan zaman yang sekarang berkembang. Sama dengan pandangan Masdar, Kiai Husen berargumen, perubahan zaman telah mampu mencipta kaum perempuan yang dulu nyaris tanpa potensi apapun menjadi berpotensi. Sementara itu, perubahan zaman menuntut manusia untuk mengolah kehidupan secara kreatif dan inovatif. Dalam hal ini, pemimpin-pemimpin berpotensi yang kreatif dan inovatif sangat dibutuhkan demi keberlangsungan hidup lebih baik. Tolak ukur kepemimpinan pun haruslah berubah, dari kategori jenis kelamin ke kategori potensi dan kemampuan. Dalam hal ini, baik laki-laki maupun perempuan, selagi ia mampu berkreasi dan berinovasi, maka ia layak jadi pemimpin. Dan penafsiran ulama pada masa lalu tentang perempuan dalam nash haruslah dirubah sesuai dengan perubahan sosial dan budaya yang berlaku. ${ }^{53}$

Kedua, baik Masdar Farid Mas'udi maupun Kiai Husen Muhammad mendasarkan pandangannya tentang kesetaraan kepemimpinan perempuan pada prinsip keadilan dalam Islam, yang dalam wacana modern memusat pada apa yang disebut dengan hak-hak asasi manusia (HAM). Masdar, misalnya,

\footnotetext{
52 Masdar Farid Mas'udi, Islam dan Hak-hak Reproduksi Perempuan, 64.

${ }^{53}$ Husen Muhammad, Fiqh Perempuan: Refleksi Kiai Atas Wacana Agama dan Jender, 25-27.
}

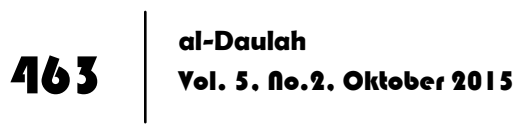


menelisik ayat tentang waris pada al-Qur'an surat an-Nisa' ayat 11-12 untuk memperkuat argumentasinya tentang keadilan jender. Di sana terdapat ungkapan (yang artinya): "...bagian laki-laki sama dengan bagian dua orang anak perempuan....". Menurutnya, ini adalah pembagian minimal, bukan maksimal. Yang penting adalah keadilan. Menurut Masdar, ayat ini sesuai dengan prinsip keadilan, karena sebelum ayat ini turun, perempuan tidak mendapatkan waris. Sesuai dengan kondisi dan struktur ekonomi keluarga saat itu, hak waris dipandang adil dengan rumusan 2:1. Selanjutnya, Masdar menggunakan kaidah, "Batasan kuantitatif yang diberikan setelah minus, pada dasarnya bukan maksimal, melainkan minimal." Artinya, dalam kasus-kasus lain, tuntutan keadilan bisa saja menghendaki pembagian laki-laki-perempuan sama banyak, atau perempuan bahkan lebih banyak.

Menurut Kiai Husen Muhammad, prinsip keadilan dalam agama tauhid (Islam) berlaku universal. Ia tidak hanya diberlakukan terhadap orang-orang mukmin, tetapi juga nonmukmin. Kiai Husen Muhammad menegaskan pendapatnya berdasarkan pada QS. Al-Mumtahanah: 8. Dengan dasar argumentasi prinsip keadilan ini, Kiai Husen Muhammad juga mengemukakan, bahwa keadilan juga harus ditegakkan dalam relasi laki-laki perempuan, sesuai dengan konteks yang berlaku, karena baik laki-laki maupun perempuan memiliki hak-hak kemanusiaan yang sama. ${ }^{54}$

Ketiga, keduanya sama-sama menonjolkan corak pemikiran populis atau membumi. Corak ini bisa ditemukan pada pandangan mereka yang berpihak pada konteks kehidupan manusia. Dalam hal ini, pembumian ajaran Islam coba mereka implimentasikan dalam hal gender, yang selama ini banyak dipahami sebagai ketentuan dari langit.

${ }^{54}$ Husen Muhammad, Islam Agama Ramah Perempuan, 21. 


\section{Perbedaan}

Sebagaimana persamaan pandangan antara Masdar Farid Mas'udi dan Kiai Husen Muhammad tentang kepemimpinan perempuan, perbedaan pandangan keduanya juga banyak ditemukan. Namun pada penjelasan ini penulis akan jelaskan perbedaan menonjol pada pandangan keduanya, yaitu:

Pertama, perbedaan keduanya terdapat pada sudut pandang mereka dalam memahami teks-teks ayat gender. Masdar Farid Mas'udi dalam memahami ayat-ayat gender lebih menonjolkan landasan berpikir arus renaissance ala Barat. Dijelaskan, secara garis besar pemikiran Masdar ini dapat diidentifikasi dalam sebuah kerangka paradigmatik yang disebutnya Islam Pembebasan, Emansipatoris, atau al-Islam at-Taharruriy. Dari sudut visi dan akar keprihatinannya, Islam Taharruri ini memiliki karakter yang berbeda dengan kedua gerakan yang kini banyak dibicarakan orang, yakni Islam Liberal (Islib) maupun antitesanya Islam Fundamentalis (Isfund). Bahkan Islam Taharruri ini bisa dikatakan kritik terhadap kedua wacana atau gerakan Islam tersebut.

Terkait dengan konteks wacana kepemimpinan perempuan, substansi yang diinginkan dari penjelasan agama tentang keadilan jender terletak pada esensi diturunkannya agama sebagai pembebas, bersifat emansipatoris. Dalam hal ini, Masdar berupaya membumikan teks ayat sebagai pembebas belenggu budaya yang menebarkan ketidakadilan, termasuk dalam ruang jender. Hal ini bisa dilihat pada penjelasan Masdar tentang kritik dirinya pada makna qawwamun dalam QS. An-Nisa' ayat 34, yang mengartikannya dengan penopang atau penguat, bukan pemimpin sebagaimana dimaknai ulama sebelumnya. Menurutnya, dengan pemaknaan penopang maka secara normatif sikap suami kepada istri bukan menguasai atau mendominasi melainkan mendukung 
dan mengayomi. Pengertian ini menurutnya lebih sesuai dengan prinsip mua'ayararoh bi al-ma'ruf.55

Sementara itu, Kiai Husen dalam usahanya membumikan teks ayat jender lebih menonjolkan argumentasi sejarah. Ini bisa dilihat, misalnya, pada penguatannya terhadap teks-teks AlQur'an seperti pada QS. Ali Imran ayat 195, An-Nahl ayat 97, dan At-Taubah ayat 71 , beberapa ayat yang menurutnya meneguhkan kesempatan sama antara laki-laki dan perempuan dalam berpolitik.

Kiai Husen menguatkan argumentasinya dengan memasukkan contoh-contoh sejarah peran perempuan di zaman Nabi, seperti peran Khadijah (donatur dakwah Nabi), Aisyah (panglima perang), Umm Salamah, dan lain sebagainya. Kiai Husen juga menunjukkan fakta sejarah seputar bai'at kesetiaan atau loyalitas pada pemerintah di zaman Nabi, di mana sejumlah perempuan sahabat Nabi seperti Nusaibah bin Ka'b, Ummu Athiyah al-Anshariyah, dan Rabi' bin al-Mu'awwadz ikut bersama laki-laki dalam perjuangan bersenjata dalam melawan penindasan dan ketidakadilan. Kata Husen, Umar bin Khattab juga pernah mengangkat al-Syifa, seorang perempuan cerdas dan terpercaya, untuk manajer pasar di Madinah. ${ }^{56}$

Kedua, pandangan Masdar Farid Mas'udi dan Kiai Husen Muhammad berbeda dalam hal kontekstualisasi makna ayat dalam kehidupan masa kini. Titik mula antara keduanya berbeda dalam hal, jika Masdar memulai argumentasinya dari substansi teks dalil, sementara Kiai Husen memulainya dari konteks dan realitas yang ada. Dengan kata lain, Masdar hendak menyatakan bahwa substansi teks (dalil) pada prinsipnya memuat segala macam perubahan sosial-budaya yang terjadi dalam kehidupan. Sementara Kiai Husen menitik tumpukan substansi teks pada konteks yang berlaku. Ini bisa dimaklumi karena keduanya

\footnotetext{
${ }_{55}$ Masdar Farid Mas'udi, Islam dan Hak-hak Refroduksi Perempuan, 62.
}

${ }^{56}$ Husen Muhammad, Islam Agama Ramah Perempuan, 166-167. 
memang berbeda dalam sudut pandang pemahaman teks (dalil dasar), sebagaimana telah dijelaskan di atas.

Perbedaan ini bisa diketahui, misalnya, pada argumentasi Masdar yang menggunakan kaidah "Batasan kuantitatif yang diberikan setelah minus, pada dasarnya bukan maksimal, melainkan minimal" sebagai penguat argumentasinya pada penafsiran ayat tentang pembagian waris antara laki-laki dan perempuan di dalam QS. an-Nisa' ayat 11-12, yang menurutnya, dalam konteks tertentu bisa saja sama.

Sedangkan dalam argumentasi Kiai Husen Muhammad yang kontekstualistik, kita bisa pahami pada kritiknya terhadap pandangan ulama terdahulu, seperti az-Zamakhsyari, Ibn Katsir, dan lain sebagainya, yang menyatakan perempuan tidak pantas mengerjakan tugas-tugas berat seperti politik, yang dalam anggapan umum hanya pantas dikerjakan laki-laki. Menurutnya, dewasa ini, pandangan seperti di atas yang menonjolkan suprioritas laki-laki saat ini tidak dapat lagi dipertahankan sebagai sesuatu yang berlaku umum dan mutlak. Ini bukan saja karena bertentangan dengan nilai-nilai universal tetapi juga tidak sesuai dengan fakta-fakta sosial (kekinian). ${ }^{57}$

Demikian persamaan dan perbedaan menonjol antara pandangan Masdar Farid Mas'udi dan Kiai Husen Muhammad tentang kepemimpinan perempuan. Sebenarnya, masih banyak perbedaan lainnya dalam mengulas masalah ini, namun hanya bersitan dari beberapa hal yang penulis sebutkan di atas.

\section{Kekurangan dan Kelebihan Pandangan Masdar Farid Mas'udi} dan Kiai Husen Muhammad tentang Kepemimpinan Perempuan

Hasil sebuah pemikiran dipastikan akan memiliki kelebihan dan kekurangan. Demikian pula pada pemikiran Masdar Farid Mas'udi dan Kiai Husen Muhammad tentang kepemimpinan perempuan, pasti juga memiliki kelebihan dan kekurangan.

\footnotetext{
${ }^{57}$ Husen Muhammad, Fiqh Perempuan Refleksi Kiai atas wacana Agama dan Gender, 25.
} 
Berikut penulis jelaskan beberapa kelebihan dan kekurangan yang terdapat pada pemikiran keduanya.

1. Kelebihan

Adapun kelebihan dari pandangan Masdar Mas'udi dan KH Husen Muhammad tentang kepemimpinan perempuan terletak pada: pertama, baik pemikiran Masdar Mas'udi maupun Kiai Husen Muhammad sama-sama memiliki unsur pencerahan bagi kemanusiaan. Prinsip keadilan dan persamaan yang dikemukakan dalam menjelaskan masalah jender ini merupakan satu pemikiran baru, yang dalam konteks masa kini sangat dibutuhkan. Bagaimanapun, tafsiran kontekstualistik keduanya terhadap ayatayat jender yang sebelumnya berparadigma "langit" menjadi terobosan baru sekaligus solusi pemikiran terhadap masalah (polemik) jender yang selama ini diperdebatkan.

\section{Kekurangan}

Adapun kekurangan keduanya dalam menjelaskan persoalan jender ini, yaitu:

Pertama, pandangan Masdar Farid Mas'udi yang lebih menonjolkan tafsir teks (ayat) yang secara liar memilah secara kreatif kategori qoth'iy-dzanny tanpa banyak mempertimbangkan hal di luar teks itu, yakni realitas dan konteks kesejarahan. Seperti pada ayat al-rijaalu qawwamuna 'ala an-nisa' (QS. An-Nisa': 34), yang menundukkan ayat tersebut pada ayat qoth'iy atau universal. Pemaknaan Masdar terhadap makna qawwamun dengan penopang dan penguat jelas merupakan kreasi pikir dirinya yang dimungkinkan jauh dari konteks kesejarahan. Dengan demikian, Masdar telah melewati argumentasi sejarah yang menyebabkan ayat tersebut turun (munasabah ayat), sehingga argumentasi yang dikemukakannya mudah dijatuhkan.

Sementara itu, pada paparan Kiai Husen, kelemahan argumentasi dapat ditemukan pada kurangnya dalil fiqh sebagai penguat tafsiran dirinya terhadap ayat atau teks jender. Analisis Kiai Husen lebih didominasi oleh dinamika perkembangan sejarah 
yang sebenarnya harus diteliti ulang juga, karena kemungkinan kesalahan penulisan sejarah bisa saja terjadi. Selain itu, terkesan, dari dominasi sejarah yang dipaparkan Kiai Husen sebagai penguat, ada upaya pemaksaan antara substansi ajaran Islam yang telah dibumbui fakta sejarah dengan konteks kekinian. Dalam paparan Kiai Husen Muhammad yang memaparkan bahwa konteks zaman yang telah berubah menuntut pula usaha perubahan tafsiran seseorang terhadap ayat-ayat jender yang dari dulu mendiskriminasi perempuan. Tampak seolah-olah ajaran agama harus mengikuti kemauan zaman. Padahal, seharusnya agama menjadi penuntun dan pengarah dan bukan yang dituntun atau diarahkan.

Demikian paparan penulis yang menjelaskan tentang persamaan-perbedaan dan kelebihan-kelemahan antara pemikiran dan pandangan Masdar Farid Mas'ud dan Kiai Husen Muhammad tentang kepemimpinan perempuan.

Dari hasil pembahasan ini, penulis dapat membandingkan tentang persamaan, perbedaan, dan metode berfikir Masdar Farid Mas'udi dan Kiai Husen Muhammad tentang konsep kepemimpinan perempuan sebagaimana tabel berikut:

\begin{tabular}{|l|l|l|}
\hline & \multicolumn{1}{|c|}{ Masdar Farid Mas'udi } & Kiai Husen Muhammad \\
\hline $\begin{array}{l}\text { Tentang } \\
\text { Kepemimpinan }\end{array}$ & $\begin{array}{l}\text { Perempuan boleh } \\
\text { menjadi pemimpin dan } \\
\text { tidak bertentangan } \\
\text { dalam agama }\end{array}$ & $\begin{array}{l}\text { Perempuan juga boleh } \\
\text { menjadi pemimpin } \\
\text { sebagaimana peran laki-laki }\end{array}$ \\
\hline $\begin{array}{l}\text { Metode } \\
\text { Berfikirnya }\end{array}$ & $\begin{array}{l}\text { Kritis-analisis melalui } \\
\text { pendekatan fikih }\end{array}$ & $\begin{array}{l}\text { Kritis, melalui pendekatan } \\
\text { kritik sejarah dan fikih }\end{array}$ \\
\hline
\end{tabular}

Sumber: hasil analisis

\section{Penutup}

Masdar Farid Mas'udi dan Kiai Husen Muhammad berpandangan bahwa kepemimpinan perempuan tidak bertentangan dalam Islam. Karena menurut Masdar dan Kiai Husen Muhammad, tidak hanya kaum laki-laki yang berhak 
menjadi pemimpin, perempuanpun juga berhak yang sama sebagaimana peran laki-laki. Kebolehan perempuan menjadi pemimpin menurut Masdar dan Kiai Husen Muhammad bukan terletak pada perbedaan jenis kelamin, melainkan karena potensi kemampuannya. Jadi menurut keduanya tidak ada larangan dan batasan bagi perempuan menjadi pemimpin.

Pandangan dan gagasan Masdar dan Kiai Husen Muhammad tentang kepemimimpinan perempuan terletak pada kontekstualisasi teks (kritik teks). Bedanya kalau Masdar menafsirkan teks tidak terlepas dengan konsep fiqihnya, sedangkan kiai Husen menafsirkan teks tidak terlepas dari sejarah dan fiqihnya. Menurut Masdar dan Kiai Husen Muhammad, teks (kitab kuning) dengan segala muatannya bukanlah kebenaran mutlak, melainkan sebuah tradisi, kebutuhan dan pendapat umum pada tempat dan zaman dikarangnya. Jadi keduanya memberikan pernyatan dan gagasan tidak sembarangan, ia tahu bagaimana asbabul wurut teks tersebut dan bagaimana sejarahnya.

\section{Daftar Pustaka}

Anam, Choirul. "Masjid Masdar: Kita Perlu Silaturrahmi Hadapi Masalah Khilafiyah". Sabtu, 5 Juni 2004, dalam http://www.nu.or.id/page.php?lang=id\&menu=news_view\&n ews_id=3101.

Bush, Robin L. Wacana Perempuan di Lingkungan NU Sebuah Perdebatan Mencari Bentuk. Jurnal Taswirul Afkar, Edisi 5. no 5 Tahun 1999.

Duwal, Qoidud. "Konsep Jilbab Dalam Hukum Islam (Studi

Pemikiran Kiai Husen Muhammad)". Skripsi, UIN Sunan Kalijaga Yogyakarta, 2009.

Fauziah, Amalia. Tentang Perempuan Islam: Wacana Gerakan. Jakarta: Gramedia, 2000.

Fuad, Mahsun. Hukum Islam Indonesia, Dari Nalar Parsipatoris Hingga Emansipatoris. Yogyakarta: LKiS, 2005. 
Ibnu Katsir. Tafsir al-Qur'an al-'Azhim, al-Qurtubi, Al-Jami li Ahkami al-Qur'an. Juz V

Imron Fauzi, "Berakar Pada Tradisi Bervisi Modern", diakses tanggal 5 September 2009 dalam http://imronfauzi.wordpress.com/ 2009/07/21/kh-masdarfarid-masudi/ 2009

Mahmud, Adnan. Pemikiran Islam Kontemporer di Indonesia. Yogyakarta: Pustaka Pelajar, 2005.

Mas'udi, Masdar Farid. Agama Keadilan, Risalah Zakat (Pajak) dalam Islam. t.tp: Pustaka Firdaus, 1991.

-------. Islam dan Hak-Hak Reproduksi Perempuan, Dialog Fiqih Perempuan. Bandung: Mizan, 1997.

Muhammad, Husen. Figh Perempuan Refleksi Kiai atas Wacana Agama dan Gender. Yogyakarta: LKiS, 2001.

-------. Islam Agama Ramah Perempuan Pembelaan Kiai Pesantren. Yogyakarta: LKiS, 2004.

Muzadi, Abdul Muchit. Fiqih Perempuan Praktis. Surabaya: Khalista, 2005.

Nasaruddin Umar, Argumen Kesetaraan Gender Perspektif Al-Qur'an, Jakarta, Paramadina, 2001.

Nuruzzaman. Kiai Husen Membela Perempuan. Yogyakarta: LKiS, 2005.

Suyuthi (al-). Al-Durra al-Mantsur al-Tafsir bi al-Ma'tsur. Juz II

Syafiq Hasyim (editor), Kepemimpinan dalam Islam, Jakarta, P3M, tt.

Thabari (al-), Ibnu Jarir. al-Jami al-Bayan'an Ta'wi Aay al-Qur'an. Juz I

Ulfiah, Ufi. Perempuan di Panggung Politik. Jakarta: Rahimah, 2007. 